\title{
Anxiety and Writing Ability of Filipino ESL Learners
}

Ryan P. Kabigting ${ }^{1 *}$, Allan S. Gumangan ${ }^{2}$, Dhonna P. Vital ${ }^{3}$, Ella Shiela V. Villanueva ${ }^{4}$, Evelyn S. Mosuela ${ }^{5}$, Fernan B. Muldong ${ }^{6}$, Katherine P. Pamintuan ${ }^{7}$, Maramina R. Mallari ${ }^{8}$, \& Mary Grace L. Sagum ${ }^{9}$ 123456789 Division of Pampanga, Justino Sevilla High School- English Department, Arayat, Pampanga, Philippines

Corresponding Author: Ryan P. Kabigting, E-mail: ryanpuyatkabigting@gmail.com

\begin{tabular}{ll}
\hline ARTICLE INFO ABSTRACT & ABT
\end{tabular}

Article History

Received: June 15, 2020

Accepted: July 14, 2020

Volume:3

Issue: 7

DOI: $10.32996 /$ ijllt.2020.3.7.14

\section{KEYWORDS}

ESL learners, writing anxiety, writing ability, English as Second Language, foreign language anxiety, Cognitive anxiety, Somatic, Anxiety, Avoidance
The study aimed at describing how L2 anxiety of writing affected the Filipino English as Second Language (ESL) learners' ability in writing. It also showed the anxiety rates, foremost type; then, the learners' writing ability. Thirty-three grade 10 ESL learners participated in. The utilization of Second Language Writing Anxiety Inventory (SLWAI) which was proposed by Cheng, and a written test as one of the requirements of their subject was done for data collection. $82 \%$ of learners marked high anxiety in writing, $18 \%$ was moderate anxiety, and none was recorded low anxiety. The leading type of anxiety in writing was cognitive; then the somatic; lastly, the avoidance behavior. In the writing ability, learners were satisfactorily rated and male and female writing ability did not significantly differ. A negatively low correlated, inverse relationship of SLWAI and performance was found between anxiety in writing and Filipino ESL learners' ability in writing using a second or foreign language. This implies that the greater the learners were anxious in writing, the lesser the achievement that a learner may have.

\section{Introduction}

Globally, English is the language which is used mostly in communication. In the Philippines, English as second language or L2 is taught as one of the required subjects until college years. Students should master the language for them to pass the subject. Language teaching in the Philippines seems to be an important concern for language teachers because English is not the first language of the Filipinos. Linguistic skills such as writing, reading, and viewing, speaking, and listening should become skilled at by ESL learners.

Writing is primary skill that should be taught and learned among ESL learners. People can use writing as one way to communicate ideas and information. For learners, communicating what they feel and think can be completed through writing.

However, using second language (i.e. English) is not easy for learners to write. The researcher interviewed among fellow teachers of English, majority of leaners still exhibited problems and hitches in paragraph writing. They could not express the ideas systematically and meaningfully. In addition, students have found out that they were not consistent with their grammar. Issues on verb forms, punctuations, capitalizations, spelling have been the primary concerns of teachers in writing activities of students. The issues presented are strengthened by Ur (2000). He agreed that learners committed mistakes in terms writing of mechanics, in punctuating, capitalizing proper names, and also spelling of the words. Learners were poor in grammar and used inappropriate words for compositions. They could not connect ideas from one sentence to the others. Confusion on how to introduce their thoughts in the beginning of the paragraph and do not know expound this in the next paragraph is observed on

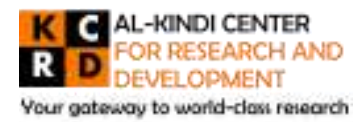

Published by Al-KindiCenter for Research and Development. Copyright (c) the author(s). This is an open access article under CC BY license (https://creativecommons.org/licenses/by/4.0/) 
their write-ups. This results in producing writing without coherence and unity. ESL Filipino learners have had difficulty in writing essays as part of the English curriculum.

Researchers and theorists focused on L2 acquisition or learning have long been cognizant that anxiety is regularly related to learning a second or foreign language. Educators and learners commonly feel that anxiety is a major hindrance to be overcome in second language learning (Horwitz, Horwitz \& Cope, 1986). There are studies that explore the different perceptions about foreign language anxiety in writing which are also related to learners' gender (Cheng, 2002; Jafari et al., 2012; Marwan, 2007; Mathew et al., 2013), the present study attempts to examine not only the level of second/foreign language anxiety in writing and gender but also its effect on the Filipino ESL students writing ability.

\section{Literature Review}

The writing process includes substance and content, organization of ideas, choice of vocabulary, language features, and mechanics. A writing task encompasses the use of simple sentences to complex or essays. Putting, discovering, and organizing feelings, beliefs, and the ideas through symbols and through a well-constructed text make the whole process. Developing these writing requires the learners to follow the process of learning on getting ideas, putting them together, getting them on the paper, and refining them into a piece of writing (Umaemah et al. 2016).

Moreover, one essential skill in language is writing. Writing is the skill that emphasis mechanical aspects of writing and grammar level, which attempt to replicate the processes of thinking and textual convention of discourse community (Johnson and Lin, 2016 and Shea, 2017). Relating to the gray areas on the significance of writing in English learning and the students' struggles in writing, Raimes (1983), indicates certain causes that specify the meaning of teaching writing. It first supports the grammatical structure, idiom, and vocabulary in which the teachers use in the class. These students are free to explore with the English language while writing. Also, students are totally involved in the language with the readers and themselves.

In addition, Zailaini et al. (2015) describe writing as a challenging undertaking, particularly for those who come from the EFL/ESL setting. In 2002, Cheng emphasized as an emotional and cognitive activity, students think and feel while they are writing. Writing using $\mathrm{L} 2$ is also deliberated as a complex method of social, cultural and background aspects, and of the learner's distinct characteristics, such as institutional requirements, parental or shared anticipations, training and assessment procedures, motivation, personality, self-confidence, learner's belief, L2 proficiency, and even gender and years in school.

Anxiety is perceived to be a crucial occurrence in the acquisition or learning of a language which is established to be an undesirable factor. It makes a vital role in the realization of learning or the lack of it. Language teachers have engaged great interest in exploring this language anxiety which, as thought of, hampers learning in the recent years (Elaldi, 2016).

In 2004, Cheng presented a multidimensional L2 writing scale - the SLWAI which conforms to a three-dimensional conceptualization of anxiety, the avoidance behavior, cognitive and somatic anxieties. Referring to the cognitive aspect of anxiety experience, it includes undesirable prospects, uneasiness with performance and concern about others' insight. The psychological effects such as being nervous and tensed as perceived by a person is an anxiety experience or the Somatic. The last type refers to an anxiety where the students avoid writing or Avoidance behavior anxiety.

Factors related to second language writing anxiety were also analyzed by Cheng in 2002. She also offered the SLWAI, an instrument to use to measure the levels and types of L2 writing anxiety (Cheng, 2004).

According to Ratnah (2018), a purposive message to a reader can be delivered by learners through writing. Learner can clarify things, and the reader can get information by reading the written messages. The assessment of language competency, recalling capability, and thinking ability is found to be the cognitive side of a productive writing skill (Javed et al. 2013).

Gender has become one of defining variables that impacts the level of anxiety in a study about writing conducted by Cheng in 2002 among the 165 students majoring in English in a university in Northern Taiwan. The study, concentrated on the anxiety in writing by gender. This revealed that gender significantly affected the level of anxiety in English writing. Consequently, learners' gender is considered an aspect relative to the high anxiety in English learning (Berk, 2017). 
It is the task for the teachers of English to regulate the learners' anxiety in writing that affects their ability to write using L2 to provide better and more favorable writing experiences among learners.

\section{Methodology}

The researchers employed correlational research design. Primarily, assessing relationships, consistency, and prediction among variables is the main purpose of the application (Ary et al., 2010). It tries to evaluate patterns of relationship among variables in one group of participants. The current study examines the relations of anxiety in writing and the ability of the Filipino learners to write using L2.

\section{Participants}

The researchers considered Justino Sevilla High School in the Division of Pampanga, Pampanga, Philippines to be the research site. Purposive sampling was the technique used in selecting the participants. This sampling technique involved the total population to be test which has particular similarities in terms of specific attributes/traits, experience, knowledge, skills, exposure to an event, etc. (Creswell, 2014). The criterion for sample selection reflected that this sample considering that the participants would provide the necesary data for the purpose of the study. This section is classified as the Grade 10 -Science, Technology and Engineering (STE) in which as early as grade 8, learners have undergone research writing and participated in journalism contests.

\section{Instrument}

Given the permission for the utilizing the SLWAI, this 22 item-questionnaire was used to determine the participants' level and the type of anxiety. SLWAI is used as a measure of writing anxiety because it has been proved highly reliable and valid (Cheng, 2004). A 0.91 Cronbach alpha coefficient, this SLWAI has good internal consistency (Cheng, 2004), in addition, it extensively measures the foreign/second language writing anxiety among students (Rezaei \& Jafari, 2014).

It followed the 5-point Likert scale with the descriptions, strongly disagree (1), disagree (2), uncertain (3), agree (4), and strongly agree (5). Items 1,3,7,9,14,17,20, and 21 were distributed for Cognitive Anxiety while items, Somatic Anxiety 2,6,8,11,13,15, and 19, and items 4,5,10,12,16,18, and 22 were for Somatic and Avoidance behavior, respectively.

65 points and above shows a high level of writing anxiety while 50 points and below designates to low level of writing anxiety, and the moderate level of writing anxiety has total score of 51-64. SLWAI is deliberated as being "highly reliable and valid by means of correlation and factor analysis" (Kırmıı and Kırmızı, 2015, p. 59).

The present had .75 as the computed Cronbach alpha coefficient of which is described acceptable of all 22 items included in the questionnaire; thus, utilizing the SLWAI has a consistent validity and reliability for this study.

Meanwhile, the researchers gave a 50-60-minute writing task to the participants to accomplish. They also considered the significance to Filipino ESL perspective as center for learners' essays. These were assessed adapting the scale of Jacobs et al. (1981) by Hedgcock and Lefkowitz (1992) in composition writing.

Content, organization, grammar, vocabulary, and mechanics were the criteria focused in the assessment. The researchers followed a 1 to 50-point scale in rating the essays. English writing ability of learners was determined by their scores in the writing task.

\section{Collection and Analysis of Data}

Writing an essay using English as the targeted language, the researchers gave the learners the topic and 50-60 minutes-time allotment to finish the task. Given with twenty minutes, participants were asked to accomplish the SLWAI. 65 points and above shows a high level of writing anxiety while 50 points and below designates to low level of writing anxiety, and the moderate level of writing anxiety has total score of 51- 64. (Rezaei, M. \& Jafari, M, 2014).

Items 1,3,7,9,14,17,20, and 21 were distributed for Cognitive Anxiety while items, Somatic Anxiety 2,6,8,11,13,15, and 19, and items 4,5,10,12,16,18, and 22 were for Somatic and Avoidance behavior, respectively. The researchers used SPSS version 20 for the analysis of the level and type anxiety in writing experienced by ESL Filipino learner from the data collected. The responses 
to SLWAI were examined descriptively (frequency and mean) using SPSS version 20. Meanwhile, Pearson $r$ determined how the SLWAI affected ability of the Filipino ESL learners' ability in writing.

\section{Results and Discussion}

1. How does the writing anxiety level of Filipino ESL learners be described?

Table 1. Descriptive level of SLWAI (General)

\begin{tabular}{lcccc}
\hline & $\mathrm{n}$ & Lowest & Highest & Mean \\
\hline High level of anxiety & 27 & 65 & 88 & 57.25 \\
Moderate level of anxiety & 6 & 51 & 64 & 12.72 \\
Low level of anxiety & 0 & 22 & 50 & 0.0 \\
\hline Total & 33 & 56 & 88 & 69.97 \\
\hline
\end{tabular}

This table 1 shows the level of the SLWAI of Filipino ESL learners. A high level of writing anxiety (Mean score $=69.97>65$ points) felt by Filipino ESL learners. Possible scores of the participants for the survey range from 22 to 110 . In which, this study shows that participants scored from 56 to 88 points. 69.75 Which is greater than 65 was marked with a high level of anxiety.

Furthermore, 27 learners (82\%) scored greater than 65 points which happened to be high anxiety level. It indicated that the level L2 writing anxiety of Filipino ESL learners is high. This is alarming and revealing that there is insufficiency of the locally contextualized writing tasks and processes.

This coincides with the findings of Jebreil, Azizifar, Gowhary, and Jamalinesari (2015); Rezaei and Jafari (2014); Wahyuni and Umam (2017). However, Salikin (2019) reported a medium level of anxiety experienced by learners of English as Foreign Language in Indonesia

2. How do Filipino ESL learners' types of anxiety in writing be described?

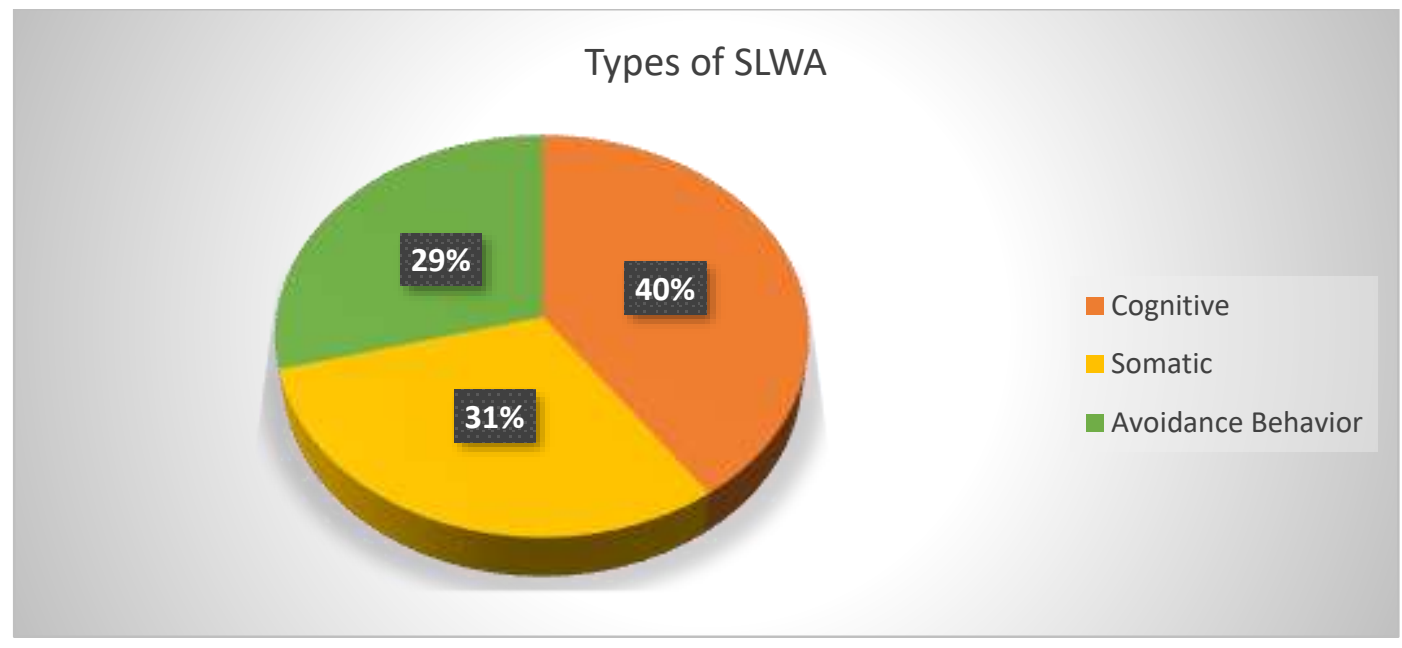

Fig. 1. Distribution of the three categories of ESL anxiety in writing

This figure 1 illustrates the three categories of ESL anxiety in writing. SLWAI suggests a three-dimensional conceptualization of anxiety- the cognitive, somatic, and avoidance anxieties (Cheng, 2004).

Cognitive anxiety category obtained the $40 \%$ which is majority of the Filipino ESL learners experienced when writing. Somatic anxiety is $31 \%$ and avoidance behavioral is 29\%. Rezaei and Jafari (2014); Salikin (2019); Zhang (2011); Wahyuni and Umam (2017) found the similar results. 


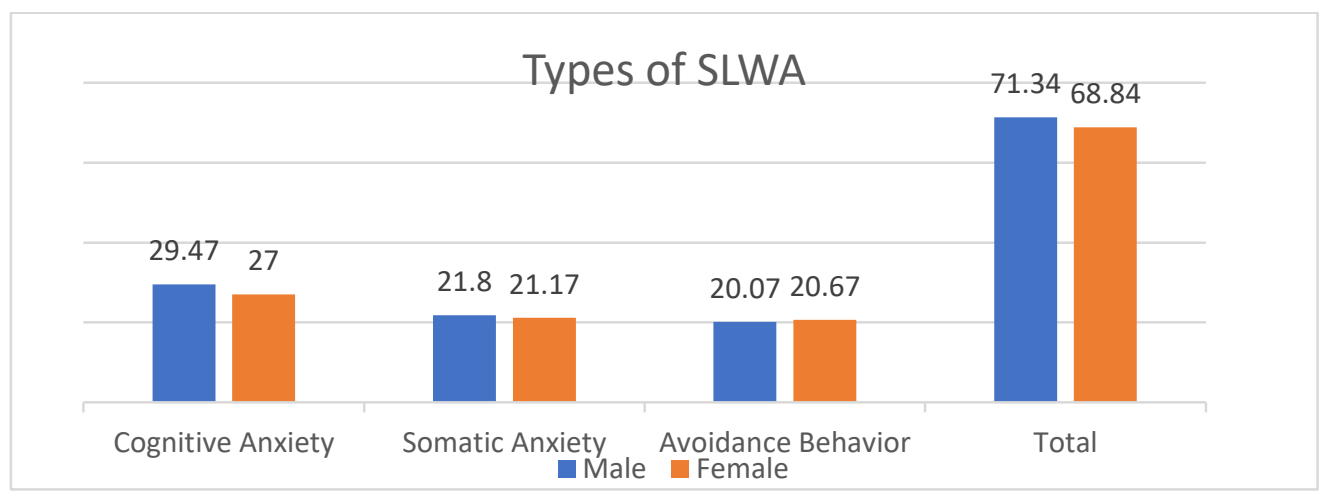

Fig. 2. Comparison between male and female types of SLWA

Figure 2 reveals the types of SLWAI of male and female Filipino ESL learners. It tells the categories of SLWA of male and the Female ESL learners. Cognitive and Somatic types of L2 writing anxiety, males suffered higher levels than females, because males got means of 29.47 (Cognitive) and 21.8 (Somatic) which are higher females' means of 27 and 21.17 , respectively, However, in terms of Avoidance behavior, females had a bit higher than males.

Based on the mean scores, a 2.5 higher obtained by male learners. This reflects that male writers feel higher anxiety than female in essay writing. This finding is supported by $\mathrm{Na}$ (2007) who found out that the males experience higher anxiety than females in Chinese EFL classrooms while Mathew, Liz, Tareq, and Islam (2013) and Jafari and Ansari (2012) who discovered that males were outperformed by females in terms of writing anxiety. Consequently, learners' gender is considered an aspect relative to the high anxiety in English learning (Berk, 2017).

\section{What is the level of Filipino ELS learners writing ability?}

Table 2. Learners' writing ability

\begin{tabular}{|c|c|c|c|c|c|}
\hline Level of Writing Ability & $\mathrm{N}$ & Minimum & Maximum & Mean & SD \\
\hline Excellent & 6 (18.18\%) & 45 & 50 & & \\
\hline Satisfactory & $22(66.66 \%)$ & 38 & 45 & 41.55 & 3.97 \\
\hline Not satisfactory & $5 \quad(15.15 \%)$ & 31 & 37 & & \\
\hline Needs Improvement & $0 \quad(0 \%)$ & 10 & 30 & & \\
\hline Total & $33(100 \%)$ & 35 & 49 & & \\
\hline
\end{tabular}

Table 3 presents the learners' writing ability. A mean score of 41.55 indicates that the writing ability of the learners was satisfactory. This also revealed that 22 or $66.66 \%$ of the learners wrote satisfactorily and only 6 or $18.18 \%$ wrote excellently. Five or $15.15 \%$ learners were rated not satisfactory. The diverse scores of learners, might probably affected by the writing anxiety.

\section{Does male writing ability significantly differ from female?}

Table 3. Significant difference of male and female writing ability

\begin{tabular}{|c|c|c|c|c|c|c|c|c|c|c|}
\hline \multicolumn{11}{|c|}{ Independent Samples Test } \\
\hline & & \multicolumn{2}{|c|}{$\begin{array}{c}\text { Levene's Test for Equality of } \\
\text { Variances }\end{array}$} & \multicolumn{7}{|c|}{ t-test for Equality of Means } \\
\hline & & \multirow[b]{2}{*}{$\mathrm{F}$} & \multirow[b]{2}{*}{ Sig. } & \multirow[b]{2}{*}{$t$} & \multirow[b]{2}{*}{$d f$} & \multirow[b]{2}{*}{ Sig. (2-tailed) } & \multirow{2}{*}{$\begin{array}{c}\text { Mean } \\
\text { Difference }\end{array}$} & \multirow{2}{*}{$\begin{array}{l}\text { Std. Error } \\
\text { Difference }\end{array}$} & \multicolumn{2}{|c|}{$\begin{array}{l}\text { 95\% Confidence Interval of the } \\
\text { Difference }\end{array}$} \\
\hline & & & & & & & & & Lower & Upper \\
\hline TestScores & $\begin{array}{l}\text { Equal variances } \\
\text { assumed }\end{array}$ & 1.756 & .195 & -1.073 & 31 & .291 & -1.489 & 1.387 & -4.318 & 1.340 \\
\hline & $\begin{array}{l}\text { Equal variances not } \\
\text { assumed }\end{array}$ & & & -1.050 & 26.364 & .303 & -1.489 & 1.418 & -4.402 & 1.425 \\
\hline
\end{tabular}

(Levene's test: $F=1.756, p$-value $=0.195,>0.05 ;$-test (equal variances): $T=-1.073, p$-value $=0.291,>0.05$ )

This table 3 shows the difference of male and female writing ability. The difference of English writing ability between male and female learners ( $p$-value $=0.291,>0.05$ ) goes beyond significant level of $5 \%$. This means that there was no significant difference 
between male and female writing abilities. It only indicates that male and female writers may have more or less the same level of writing ability.

5. Does the level of SLWA significantly affect Filipino ESL learners writing ability?

Table 4. Correlation between SLWA and ESL learners writing ability

\begin{tabular}{lcc}
\hline Variables & r-value & Relationship \\
\hline Writing Anxiety vs Writing Ability & -.254 & Low \\
\hline
\end{tabular}

This table 4 presents the correlation between anxiety and writing ability. The computed r-value -.254 signified that there was negative low correlation on the writing anxiety and ability of Filipino ESL learners score in writing task. It means that ESL writers who have had higher writing anxiety received lower score in writing task. A similar finding revealed by Zhang (2011) that learners who had found with higher anxiety in writing had lower proficiency grades in writing than those who with lower writing anxiety. Also, Kabigting and Nanud (2020) found out that anxiety affected the performance of the learner inside the classroom.

\section{Conclusion}

This purposely describing how L2 anxiety of writing affected the Filipino English as Second Language (ESL) learners' ability in writing. It was found out that Filipino ESL learners were highly anxious in writing essay. Moreover, the leading type of anxiety in writing was cognitive; then the somatic; lastly, the avoidance behavior. Cognitive and Somatic types of L2 writing anxiety, males suffered higher levels than females. In the writing ability, learners were satisfactorily rated and male and female writing ability did not significantly differ. There was negative low correlation on the writing anxiety and ability of Filipino ESL learners score in writing task. It means that ESL writers who have had higher writing anxiety received lower score in writing task. Filipino ESL learners are affected by the writing anxieties they feel when writing. Difficulty in writing due to anxieties may create fear of making mistakes and impede development of writing essay in the target language. This research is only limited to small number of participants, their second language writing anxieties and writing ability. There may be researchers who are willing to use found results of the current to study more and different factors that may affect ESL learners writing ability such as the causes, teaching strategies and motivation in writing.

\section{References}

[1] Al-Shboul, Y., \& Ibrahim F. H. (2015). Causes of writing apprehension through students' perspective. Journal of Language Teaching and Research, 6(3), 535-544. doi: 10.17507/jltr.0603.08.

[2] Ary, D., Jacob, L. C., \& Sorensen, C. (2010). Introduction to research in education (8th ed.). Thomson Wadsworth.

[3] Berk, R. R \& Unal, E. (2017). Comparison of writing anxiety and writing dispositions of sixth, seventh and eighth grade students. International Journal of Instruction, 10(1), 237-254. doi: 10.12973/iji.2017.10115a.

[4] Cheng, Y. S. (2002). Factors associated with foreign language writing anxiety. Foreign Language Annuals, 35(5), 647-56.

[5] Cheng, Y.S. (2004). A measure of second language writing anxiety: Scale development and preliminary validation. Journal of Second Language Writing, 13(4), 313-335. doi:10.1016/j.jslw.2004.07.001.

[6] Elaldi, S. (2016). Foreign language anxiety of students studying English language and literature: A sample from Turkey. Educational Research and Reviews, 11 (6), 219-228. DOI: 10.5897/ERR2015.2507.

[7] Hedgcock, J., \& Lefkowitz, N. (1992). Collaborative oral/aural revision in foreign language writing instruction. Journal of Second Language Writing, 1(3), 255-276.

[8] Horwitz, E.K., Horwitz, M.B\& Cope, J. (1986). Foreign language classroom anxiety. The Modern Language Journal, 70,125-132.

[9] Jafari, N. \& Ansari, D. N. (2012). The effect of collaboration on Iranian EFL learners' writing accuracy. International Education Studies, 5(2), 125-131. doi: 10.5539/ies.v5n2p125.

[10] Javed et al. (2013). A Study of Students' Assessment in Writing Skills of the English Language: International Journal of Instruction, 6(2).

[11] Jebreil, N., Azizifar, A., Gowhary, H., \& Jamalinesari, A. (2015). Study on Writing Anxiety among Iranian EFL Students. International Journal of Applied Linguistics and English Literature, 4(2), 68-72. doi:http://dx.doi.org/10.7575/aiac.ijalel.v.4n.2p.68

[12] Johnson D and Lia C.H. (2016). Evaluating genre-based writing instruction: Materials, instructional mode, and student learning styles: The Asian EFL Journal, 18(2), 216-243.

[13] Kabigting, R. P. \& Nanud, J.A.G. (2020). English Language Classroom Anxiety and Performance of Senior High School Learners. International Journal of Linguistics and Translation Studies, 1(2).

[14] Kırmızı, Ö. \& Kırmızı, G. D. (2015). An investigation of L2 learners' writing self-efficacy, writing anxiety and its causes at higher education in Turkey. International Journal of Higher Education, 4(2), 57-66.

[15] Marwan, A. (2007). Investigating students' foreign language anxiety. Malaysian Journal of EFT Research, 3 (1), pp. 37-55.

[16] Mathew, P., Job, L. M., Damen, T. A., \& Islam, M. R. (2013). An Arab EFL context: Does variance in anxiety and motivation across gender impact language attainment? Studies in Literature and Language, 6(3), pp. 14-22.

[17] $\mathrm{Na}$, Z. (2007). A study of high school students' English language anxiety. Asian EFL Journal, 9(3), 22-34. 
[18] Ratnah. (2018). Improving Writing Skills by Using Authentic Materials in Indonesian Vocational School: The Asian EFL Journal, 20 (7), 124-129.

[19] Rezaei, M. \&Jafari, M. (2014). Investigating the Levels, Types, and the Cause of Writing Anxiety among Iranian EFL Students: A Mixed Method Design. Procedia- Social and Behaviour Sciences, 98: 1547.

[20] Salikin, H. (2019). Factors affecting male and female Indonesian EFL students' writing anxiety. Indonesian Journal of Applied Linguistics, 9, 316-323. doi: 10.17509/ijal.v9i2.20229

[21] Shea P. D. (2017). Shifting Positions: The Development of Textual Features and Academic Voice in a University Writing Seminar: The Asian ESP Journal, 13(2), 7-34.

[22] Umaemah, A., Latief, M. A., \& Irawati, E. (2016). The Use of raft strategy to improve the students' writing ability. Elt Echo, 1(1).

[23] Wahyuni, S \& Umam, M. K. (2017). An analysis on writing anxiety of Indonesian EFL college learners. Journal of English Education and Linguistics Studies, 4(1), pp. 103- 126. doi: 10.30762/jeels.v4i1.333

[24] Zailaini, M. A., Mohamed, M. F., Ismail, W. M., Ali, S. K. S., \& Muzammil, A. G. (2015). Writing skill in Arabic language essay in Malaysian secondary school. International Journal of Social Science and Human Behavior Study, 2(2), 135-139.

[25] Zhang, H. (2011). A study on ESL writing anxiety among Chinese English majors - Causes, effects and coping strategies for ESL writing anxiety. https://www.diva-portal.org/smash/get/diva2:426646/FULLTEXT02.pdf

\section{K C AL-KINDI CENTER $\mathbf{R}$ D FOR RESEARCH AND} Your gateway to world-class research
C2020 The Author(s). This open access article is distributed under a Creative Commons Attribution (CC-BY) 4.0 license.

You are free to:

Share - copy and redistribute the material in any medium or format.

Adapt - remix, transform, and build upon the material for any purpose, even commercially.

Under the following terms:

Attribution - You must give appropriate credit, provide a link to the license, and indicate if changes were made.

You may do so in any reasonable manner, but not in any way that suggests the licensor endorses you or your use. No additional restrictions

International Journal of Linguistics, Literature and Translation is published by Al-Kindi Center for Research and Development.

Why Publish with Us?

Indexed in world-class databases

Open access format of published content ensures maximum visibility

Prestigious Editor-in-Chief with a strong expertise in the field

Prompt submission and review process

Retention of full copyright of your article

Nominal article processing charges (APCs)

Rapid online publication of your paper following expert peer review

Every article is provided with DOI (Digital Object Identifier)

Free certificate of Article publication

Extensive global readership and online visibility

Discounts and waivers for authors in developing regions

Submit your manuscript to International Journal of Linguistics, Literature and Translation at editor@ijllt.org 